\title{
Redescription of Pavelius uschakovi (Annelida: Ampharetidae)
}

\begin{abstract}
I.A. Jirkov
Hydrobiology Department, Biological Faculty, Moscow State University, Moscow, 119991 Russia. E-mail:ampharete@yandex.ru
\end{abstract}

ABSTRACT: Pavelius uschakovi Kuznetsov et Levenstein, 1988 is re-described based on type and topotype specimens. It was shown: that in contrast to the original description, the type specimens have unilobed rather than trilobed prostomia, with two nuchal organs; the prows of the uncini have buttons, tapering with a filament, which are visible under DIC only and so overlooked in the original description. Males have nephridial papillae behind the notopodia of TU1; absent in females. Comparison of the type specimens of P. uschakovi with syntypes of Sabellides elongatus Ehlers, 1913 (type species of Neosabellides Hessle, 1917) leads to the conclusion that Pavelius Kuznetsov et Levenstein, 1988 should be treated as a junior synonym of Neosabellides.

How to cite this article: Jirkov I.A. 2018. Redescription of Pavelius uschakovi (Annelida: Ampharetidae) // Invert. Zool. Vol.15. No.4. P.340-347. doi: 10.15298/invertzool. 15.4.03

KEY WORDS: Neosabellides, sexual dimorphism, seeps.

\section{Переописание Pavelius uschakovi (Annelida: Ampharetidae)}

\section{И.А. Жирков}

Кафедра гидробиологии, биологический факультет, Московский государственный университет имени М.В. Ломоносова, Москва, 119991 Россия. E-mail: ampharete@yandex.ru

РЕЗЮМЕ: На основе изучения типов и топотипов переописан Pavelius uschakovi Kuznetsov et Levenstein, 1988. Особи вида, в отличие от оригинального описания, имеют нелопастной (а не трехлопастной) простомиум с двумя нухальными органами и маленький зуб на неврохетах, заканчивающийся филаментом, видным только с использованием контраста Номарского и, вероятно, поэтому не замеченный при описании вида. Самцы имеют нефридиальные папиллы позади нотоподий TU1; эти папиллы отсутствуют у самок. Сравнение типовых экземпляров P. uschakovi с синтипами Sabellides elongatus Ehlers, 1913, типового вида Neosabellides Hessle, 1917, позволяет рассматривать Pavelius Kuznetsov et Levenstein, 1988 как младший синоним Neosabellides.

Как цитировать эту статью: Jirkov I.A. 2018. Redescription of Pavelius uschakovi (Annelida: Ampharetidae) // Invert. Zool. Vol.15. No.4. P.340-347. doi: 10.15298/ invertzool.15.4.03

КЛЮЧЕВЫЕ СЛОВА: Neosabellides, половой диморфизм, сипы. 


\section{Introduction}

Pavelius uschakovi Kuznetsov et Levenstein, 1988 is a very common and abundant polychaete in the methane seeps of the Sea of Okhotsk (Kuznetsov, Levenstein, 1988). However, investigation of new material shows that the original description is partly incorrect and misses some important taxonomic traits. Moreover, my preliminary observations demonstrated that main diagnostic characteristics of genus Pavelius match with that of genus Neosabellides.

Genus Neosabellides is listed in the World Polychaeta database (Read, Fauchald, 2018) as valid, however its type species $N$. elongatus (Ehlers, 1912) accepted as Ampharete elongata (Ehlers, 1913) (Read, Fauchald, 2018). If type species of a genus moved to another genus (Ampharete is this case) it inevitably require accepting Neosabellides as junior synonym of Ampharete. So, this situation is controversial and requires special consideration.

In one of the recent taxonomic papers it was mentioned that "type specimen of $P$. uschakovi was not available for examination because it is lost" (Reuscher, Fiege, 2016). However, it was found in a good state and available for examination in the collections of Zoological Institute of Russian Academy of Sciences, St.-Petersburg, Russia.

The goal of the present paper is to clarify the taxonomic status of $P$. uschakovi, based on the new material from the collections of Hydrobiology Department of Moscow State University and type material, to add valuable information on the species' biology. Additionally, to define status of genus Neosabellides, type specimens of the type species A. elongata were studied.

\section{Material and methods}

Material studied includes the type, paratype (deposed in ZIN), topotypes (deposed in HDMSU) and all syntypes of Sabellides elongatus Ehlers, 1913 deposed in ZMH.

Photographs were taken at the PP Shirshov Institute of Oceanology, Russian Academy of
Sciences, Moscow, using a Leica DFC490 camera mounted on either a Leica M165C stereomicroscope or a Leica DMI 4000B compound microscope; and at the Department of Invertebrate zoology, Biological Faculty, Moscow State University, using a Leica DFC425C camera mounted on a Leica DMI 5000B compound microscope. The latter microscope was fitted with differential interference contrast (DIC), also known as Nomarski interference contrast (NIC). In order to increase contrast, specimens were stained with a solution of methylene blue in water. For scanning electron microscopy (SEM), specimens stored in $70-75 \%$ ethanol were placed in $100 \%$ ethanol and $100 \%$ acetone and critical point dried using $\tilde{N} O 2$ as a transition fluid. After drying, the specimens were sputter coated with gold. SEM micrographs were taken in a Camscan S-2 Cambridge Instrument Scanning Electron Microscope. The SEM photographs were taken at the M.V. Lomonosov User Facilities Center, Moscow State University.

\section{Used abbreviations:}

$\mathrm{S}$ - segment, TS - thoracic segment, TU thoracic unciniger, $\mathrm{AU}$ - abdominal unciniger; number after abbreviation specifies the segment, for example TU1 means $1^{\text {st }}$ thoracic unciniger.

HDMSU - Hydrobiology Department, Faculty of Biology, Moscow State University, Russia; ZMH - Zoologisches Institut und Zoologisches Museum, Universität Hamburg, Germany; ZIN - Zoological Institute of Russian Academy of Sciense, St.-Petersburg, Russia.

\section{Systematics}

\section{Neosabellides Hessle, 1917}

Type species: Sabellides elongatus Ehlers, 1913 by monotypy.

Diagnosis. Prostomium unilobed, anteriorly rounded, with two nuchal transverse organs, separated medially. Neuropodia of two types: tori in thorax, AU1 and AU2; remaining AU neuropodia pinnuli.

Remarks. Ehlers (1912) listed Sabellides elongatus sp.n. without any description, so it 
fails to conform to Article 12 of ICZN (2018) and thus is nomen nudum. Later he published detailed description of the species on nearly three pages with six figures (Ehlers, 1913). This description conforms to Article 12, so Sabellides elongatus Ehlers, 1913 is the valid species name. Hessle (1917) listed Ehlers (1913) in synonymy to Sabellides elongatus Ehlers, 1912, so type species of Neosabellides should be Sabellides elongatus Ehlers, 1913. This species was already designated as type species of Neosabellides by Hartman (1959) as Sabellides elongatus (Ehlers, 1913), by Fauchald (1977) as Neosabellides elongata Hessle, 1917, and by Holthe (1986) as Sabellides elongatus (Ehlers, 1913). So, the proposal of Read \& Fauchald (2018) to transfer $N$. elongata in the genus Ampharete not confirmed by any arguments and should be rejected.

Previously (Jirkov, 2011), I supposed that Amythas membranifera Benham, 1921 may belong to this genus. However, studies of the new material demonstrated that it belongs to another genus.

Thus Neosabellides in accepted here sense includes six valid species

N. australiensis Hartmann-Schröder, 1981;

N. elongatus (Ehlers, 1913) as Sabellides;

N. makranensis (Reuscher et Fiege, 2016) as Pavelius;

N. oceanica (Fauvel, 1909) as Sabellides;

N. smileyi (Kongsrud, Eilertsen, Alvestad, Kongshavn et Rapp, 2016) as Pavelius;

N. uschakovi (Kuznetsov et Levenstein, 1988) as Pavelius.

Besides two other species are of doubtful validity:

N. litoralis Annenkova, 1934. Original description is not informative enough to be sure in its genera assignment, type absent in ZIN;

N. lizae Alvestad et Budaeva, 2015. According to the original description, this species differs from $N$. australiensis in "having 14 rather that 16" AU (p. 63). However investigation of the type specimens of N. australiensis (ZMH P16498, P-16499) demonstrated that they have 15-17 AU, so this variability make the difference in a number of AU of a low value. Both species were described from shallow waters of Australia, this fact increases doubts in validity of N. lizae.

Neosabellides uschakovi (Kuznetsov et Levenstein, 1988) emended, comb.n.

Figs $1-4$.

Pavelius uschakovi Kuznetsov et Levenstein, 1988: 821-825, figs $1-3$.

Material. Holotype ZIN 1/50561, paratype 2/50562; type locality: $50^{\circ} 30.90^{\prime} \mathrm{N} 155^{\circ} 18$. 09'E, 792-804 m. Topotypes R/V Akademik M.A. Lavrentjev, cruise 61. station LV61-13-1, 26.05.2013, $50^{\circ} 30.929^{\prime} \mathrm{N} 155^{\circ} 18.411^{\prime} \mathrm{E}, 777$ m, 7 specimens; station LV61-13-7, 31.05.2013, $50^{\circ} 30.917^{\prime} \mathrm{N} 155^{\circ} 18.421^{\prime}$ E, $778 \mathrm{~m}, 6$ specimens.

Additional material: Sabellides elongatus Ehlers, 1913; 3 syntypes: ZMH V-8597.

Description (based on all material examined). Prostomium unilobed, anteriorly rounded, with two nuchal transverse organs, separated medially by a distance equal to half the length of a single one (Figs 1A, 2A-C). Buccal tentacles smooth, grooved. Four pairs of branchiae; attachment points form a straight transverse row (Fig. 1A). Third from the outermost branchiophore clearly connected to the notopodia of S6. Paleae very small (Figs 1B, 2D). Notopodia of S4 poorly developed. Notopodia of S5 also distinctly smaller than those of S6. 15 TC, 12 TU. Modified notopodia or neuropodia; parapodial ridges absent. Thirteen of the worms have a complete abdomen, with 21-24 AU (seven, including holotype, have $23 \mathrm{AU}$ ). The number of AU does no depend on the length for worms of 18-31 mm. Thoracic neuropodia and neuropodia of AU1 and AU2 are tori; other abdominal neuropodia are pinnuli (Fig. 1C, D). No neuropodial cirri or rudimentary abdominal neuropodia. Pygidium without papillae. Males with large nephridial papillae behind notopodia of TU1 and smaller papillae below notopodia of TC1 and TC2 (Fig. 1B, pointed). Size of papillae of TU1 varies from poorly developed (but quite visible in methyl blue stained worms) up to larger than the notopodial lobe of TU1. Females have no trace of such papillae; this was not 


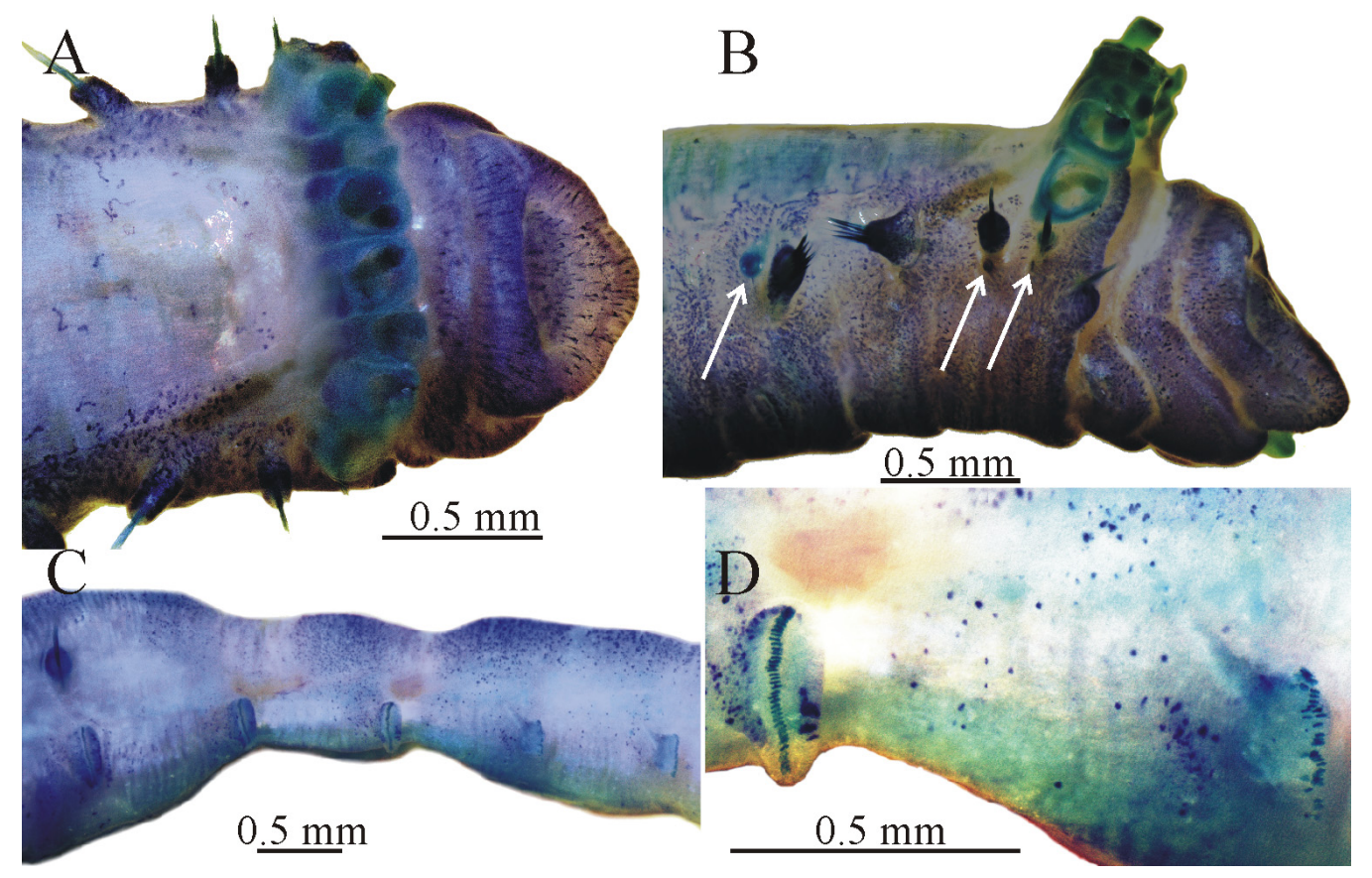

Fig. 1. Stereomicroscope microscope morphology of Neosabellides uschakovi.

A - dorsal view of anterior part; B - lateral view of anterior part (nephridial papillae pointed); C — last TU and four first AU; D - AU2 and AU3. All specimens from st. LV61-13-1 and are stained with methylene blue.

Рис. 1. Морфология Neosabellides uschakovi, видимая под световым микроскопом.

А - передняя часть, вид со спины; В - передняя часть, вид сбоку (стрелки указывают на нефридиальные папиллы); C - последний TU и четыре первых AU; D - AU2 и AU3. Bсе экземпляры со ст. LV61-13-1 и окрашены метиленовым синим.

mentioned in the original description. Additional material includes three females and ten males.

Uncini of tori with teeth in single or, partly, in double rows, with minute teeth at their base; those of pinnuli similar, but mainly with teeth in double rows and the minute teeth are more numerous, each with two long tendons, attached to anterior and posterior processes. Prow with button tapering with filament; however the button and filament are not visible either under SEM (Fig. 3) or compound in light field (Fig. 4B, D, F, I), but only in DIC (Fig. 4A, C, E, H). The filaments are probably part of sacs that enclose each uncinus. Tubes, according to the original description, semi-translucent and incrusted with dark sand grains; all specimens examined for this study had been removed from their tubes. Fixed worms colorless; living worms, according to the original description, bright red.
Taxonomic remarks. Original description says: "prostomium trilobed"; however, in reality it is unilobed and with the nuchal organs, which appear as furrows partly separated the prostomium into lobes. It also has no information on the structure of the neuropodia or their variation along the body, on the presence of filaments at the uncinal button, and on sexual dimorphism.

Worms with an everted pharynx may have furrows, resembling the furrows of ampharetids that have a three-lobed prostomium (Fig 2A, pointed). This is probably the reason why the species' authors believed that it had a threelobed prostomium.

As far as I know, the filaments of the uncinal button have not been described previously in Ampharetidae, probably due to the need for DIC to observe them. So, I do not think that 


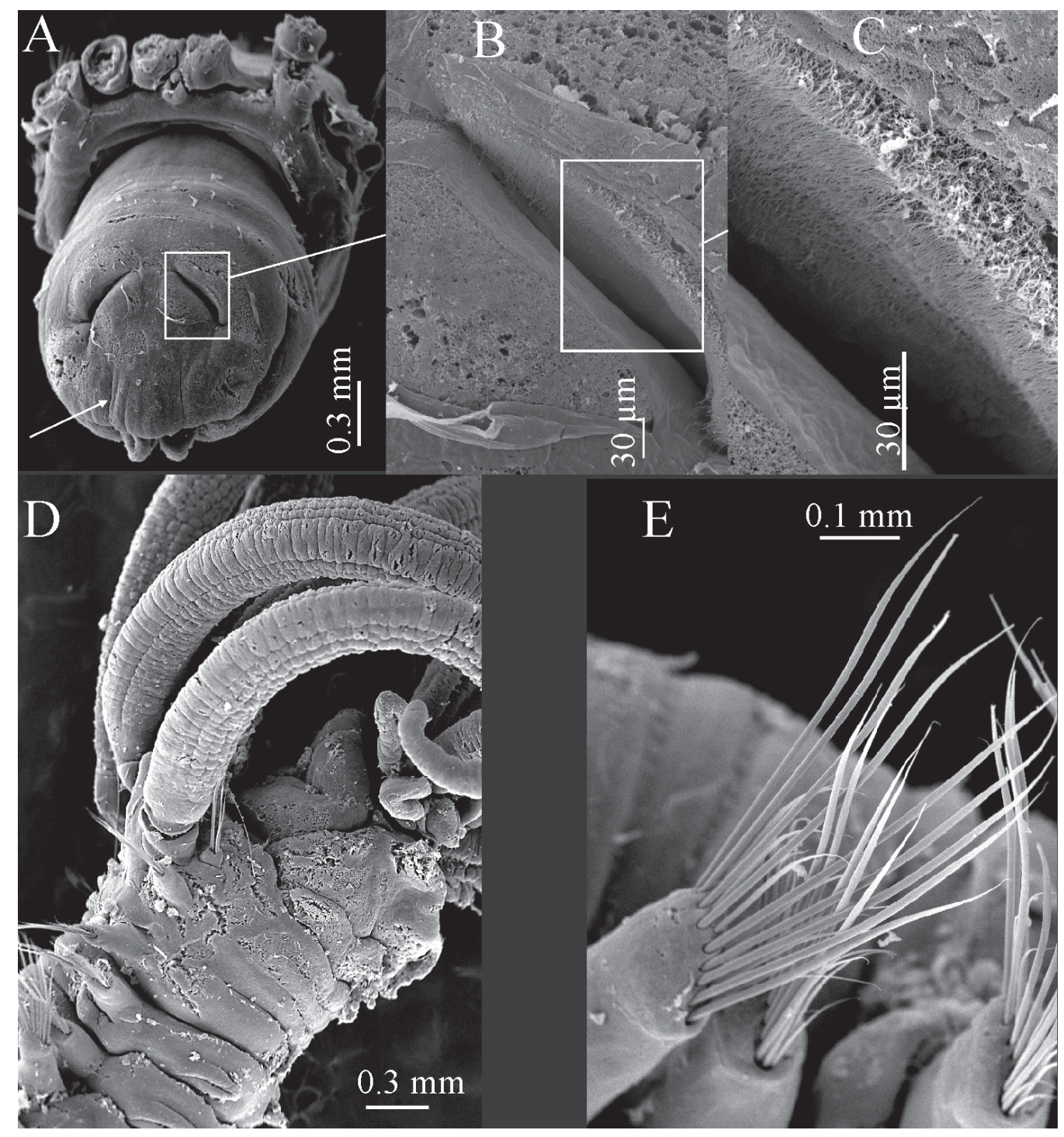

Fig. 2. SEM morphology of Neosabellides uschakovi.

A - prostomium, whole view (longitudinal furrow indicated); B - nuchal organ; C — detail of nuchal organ; D lateral view of anterior part; E - notopodia. Specimen from st. LV61-13-1.

Рис. 2. Морфология Neosabellides uschakovi, видимая под сканирующим микроскопом.

A - общий вид простомиума (стрелка указывает на продольную борозду); В — нухальный орган; C - деталь нухального органа; D — передняя часть, вид сбоку; Е — нотоподии. Экземпляр со ст. LV61-13-1.

these filaments are specific for N. uschakovi, but expect that they will be discovered in other Ampharetidae, when DIC is used.

Previously I included this species in Phyllocomus Grube, 1877 (Jirkov, 2011). However, closer examination shows that Pavelius has two types of neuropodia: tori (thorax and two first AU) and pinnuli (the rest of the abdomen), while Phyllocomus has only one type of neuropodia along the body, intermediate in shape between tori and pinnuli (more similar to tori). On the other hand, the types of the type species of 

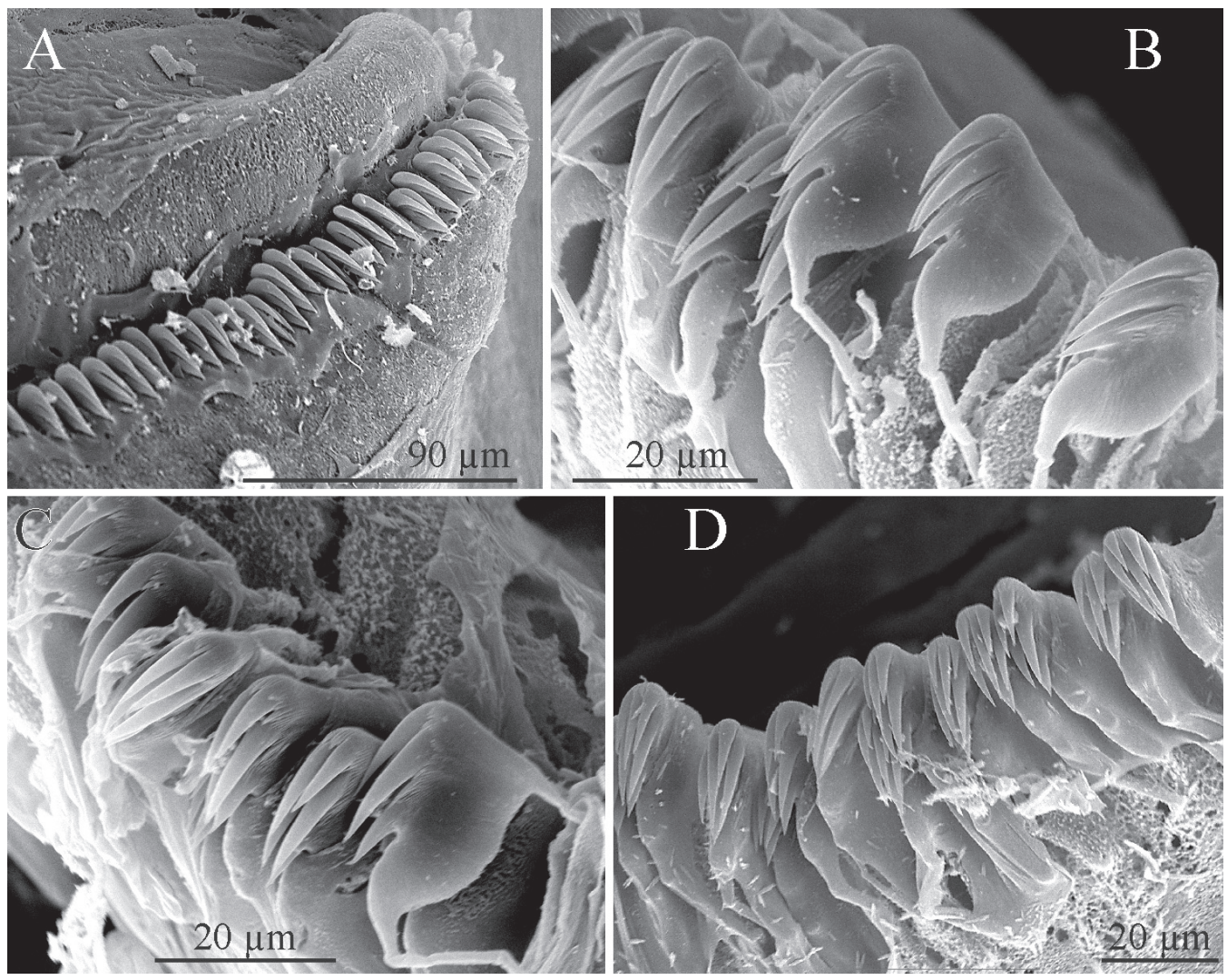

Fig. 3. Uncini of Neosabellides uschakovi SEM photos.

A - uncini AU2; B - uncini AU3; C - uncini AU6; D - uncini AU12. All specimens from st. LV61-13-1.

Fig. 3. Неврохеты Neosabellides uschakovi фотографии сканирующим микроскопом.

A - неврохеты AU2; B - неврохеты AU3; C - неврохеты AU6; D - неврохеты AU12. Все экземпляры со ст. LV61-13-1.

Neosabellides, $N$. elongatus, have an identical prostomial structure and two types of neuropodia changing after AU2. As there is no other character to distinguish Pavelius from Neosabellides, these genera should be accepted as synonyms. Based on their perfect original descriptions, the other known valid species of Pavelius: P. makranensis Reuscher et Fiege, 2016 and P. smileyi Kongsrud et al., 2017, undoubtedly belong to the same genus as $P$. uschakovi and so should be transferred to Neosabellides.

Distribution. All known material (type and topotypes) has been collected from a very small region of the Sea of Okhotsk: $50^{\circ} 30,77^{\prime} \mathrm{N}-$ $50^{\circ} 31,81^{\prime} \mathrm{N} 155^{\circ} 18,09^{\prime} \mathrm{E}-155^{\circ} 18,60^{\prime}$ E $765-$ $810 \mathrm{~m}$.

Biology. Worms build large aggregations of tubes, up to 5000-7000 specimens per sq. m (Kuznetsov, Levenstein, 1988; Dr. S.V. Galkin, IO RAN, pers comm.). Sexual dimorphism in development of large nephridial papillae in male only had not previously been reported for Ampharetidae; the closest relative having this feature is the terebellid Nicolea zostericola Örsted, 1844. In immature specimens of this species, sexes also differ in the presence (male) or absence (female) of nephridial papillae on TC3 and TC4 (=S6 and $\mathrm{S} 7$ or $=\mathrm{TU} 2$ and TU3), so it allows to make assumptions, that $P$. uschakovi has similar life- 


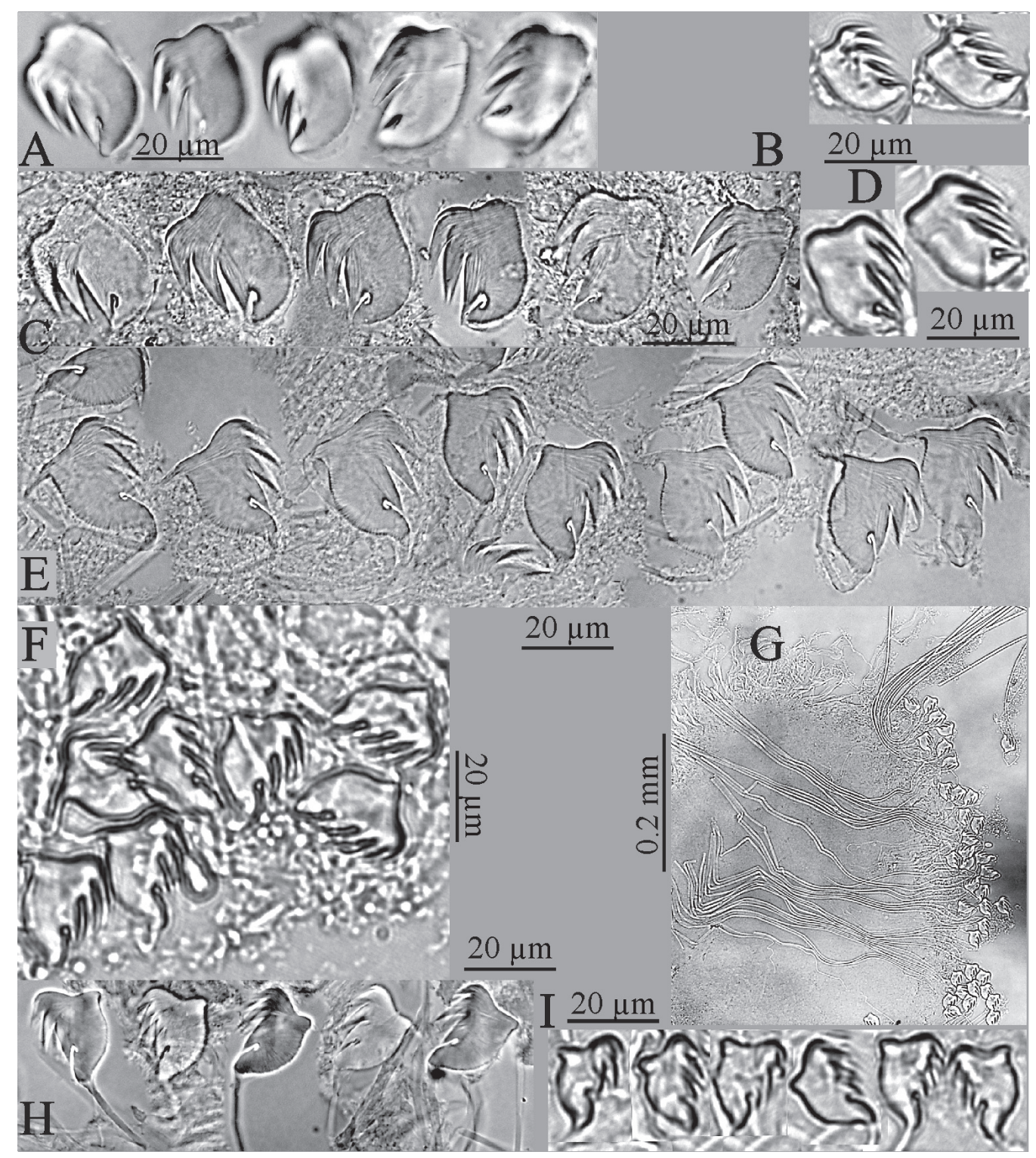

Fig. 4. Uncini of Neosabellides uschakovi compound microscope photos.

A, B - uncini TU1; C, D - uncini AU2; E-G - uncini AU3; H, I - uncini AU3 counting from the pygidium. A, C, E, H - DIC. B, D, F, I - bright field. C-I from the same slides. All specimens from st. LV61-13-1.

Fig. 4. Неврохеты Neosabellides uschakovi фотографии светового микроскопа.

A, B - неврохеты TU1; C, D - неврохеты AU2; E-G - неврохеты AU3; H, I - неврохеты AU3 от пигидия. A, C, Е, H - контраст Номарского. В, D, F, I - светлое поле. C-I с тех же препаратов. Все экземпляры со ст. LV61$13-1$.

cycle with life span of about 1 year, worms of different sexes mating before spawning, egglaying results in cocoon formation, for two to three weeks development larvae inside the co- coons, and their escaping from the cocoons with several chaetigers and at least one tentacle (Eckelbarger, 1974). The difference in sex ratios in N. uschakovi is not statistically significant. 


\section{Acknowledgements}

The author thanks Prof. V.V. Malakhov (Lomonosov Moscow State University) and Dr. A.F. Sazhin (P.P. Shirshov Institute) for the use of equipment for preparing photographs. Dr. S.V. Galkin for material and data on species biology. Thanks also to Dr T.M. Worsfold (APEM Ltd. UK) for edits to the English, to Prof. T.A. Britayev and two anonymous reviewers for valuable advises.

The SEM was performed with financial support from the Ministry of Education and Science of the Russian Federation.

This study was financially supported by a State Research Program granted to Moscow State University (project No. AAAA-A16116021660062-9 Hydrobiology Dept.) and by the Russian Science Foundation (grant number 14-50-00029) in preparing slides.

\section{References}

Alvestad T., Budaeva N. 2015. Neosabellides lizae, a new species of Ampharetidae (Annelida) from Lizard Island, Great Barrier Reef, Australia // Zootaxa. Vol.4019. No.1. P.61-69.

Annenkova N.P. 1934. Kurze Übersicht der Polychaeten der Litoralzone der Bering-Insel (Kommador-Inseln) nebst Beschreibung neuer Arten // Zoologischer Anzeiger. Bd.106. H.12. S.322-331.

Benham W.B. 1921. Polychaeta // Australian Antarctic Expedition 1911-1914, Scientific Reports, Series C - Zoology and Botany. Sydney. William Applegate Gullick, Government Printer. Phlllip-street. Vol.6. Pt.3. 128 p.

Eckelbarger K.J. 1974. Population biology and larval development of the terebellid polychaete Nicolea zostericola // Marine Biology. Vol.27. P.101-113.

Ehlers E 1912. Polychaeta // National Antarctic Expedition 1901-1904 London. Natural History Vol.VI. Zoology and Botany. 32 p., pl. I-III.

Ehlers E. 1913. Die Polychaeten-Sammlungen der deutschen Südpolar-Expedition, 1901-1903 // Deutsche Südpolar-Expedition 1901-1903 im Auftrage des Reichsamtes des innern herausgegeben von Erich von Drygalski Leiter Expedition. Bd.13. Hf.4. S.397-598. P1. XXVI-XLVI.

Fauchald K. 1977. The polychaete worms. Definitions and keys to the orders, families and genera // Natural
History Museum of Los Angeles County. Science Series. Vol.28. 188 p.

Fauvel P. 1909. Deuxième note préliminaire sur les polychètes provenant des campagnes de l'Hirondelle et de la Princesse-Alice, ou déposées dans la Musée Océanographique de Monaco // Bulletin de l'Institute Océanographique de Monaco. Vol.142. 76 p.

Hartman O. 1959. Catalogue of the polychaetous annelids of the world. Part I and II // Allan Hancock Foundation Publ. Occas. Pap. Vol.23. 628 p.

Hartmann-Schröder G. 1981. Zur Kenntnis des Eulitorals der australischen Kusten unter besonderer Berucksichtigung der Polychaeten und Ostracoden. Teil 6. Die Polychaeten der tropisch-subtropischen Westkuste Australiens (zwischen Exmouth im Norden und Cervantes im Suden) // Mitteilungen aus dem Hamburgischen zoologischen Museum und Institut. Bd.78. P.19-96.

Hessle Ch. 1917. Zur Kenntnis der terebellomorphen Polychaeten // Zoologiska bidrag från Uppsala. Bd.5. P.39-258. Plates I-V.

Holthe T. 1986. Evolution, systematics, and distribution of the Polychaeta Terebellomorpha, with a catalogue of the taxa and a bibliography // Gunneria. Vol.55.236 p.

Jirkov I.A. 2011. Discussion of taxonomic characters and classification of Ampharetidae (Polychaeta) // Italian Journal of Zoology. Vol.78. Suppl.1. P.78-94. http:// dx.doi.org/10.1080/11250003.2011.617216

ICZN. 2018. International Code Of Zoological Nomenclature at http:/www.nhm.ac.uk/hosted-sites/iczn/code/ (accessed on 28.10.2018)

Kongsrud J.A., Eilertsen M.H., Alvestad T., Kongshavn K., Rapp H.T. 2017. New species of Ampharetidae (Annelida: Polychaeta) from the Arctic Loki Castlevent field // Deep-Sea Research II Vol.137. P.232-245. http://dx.doi.org/10.1016/j.dsr2.2016.08.015

Kuznetsov A.P., Levenstein R.Ya. 1988. [Pavelius uschakovi gen. et. sp. n. (Polychaeta, Ampharetidae) from Paramushir gas hydrate spring in the Okhotsk Sea] // Zoologicheskiy zhurnal. Vol.67. No.6. P.819-825 [in Russian, with English summary].

Malmgren A.J. 1866. Nordiska Hafs-Annulater // Öfversigt af Königlich Vetenskapsakademiens förhandlingar. Stockholm. Bd.22. H.5. S.355-410.

Read G., Fauchald K. 2018. World Polychaeta database. Neosabellides Hessle, 1917. Accessed through: World Register of Marine Species at: http://www. marinespecies.org/aphia.php? $\mathrm{p}=$ taxdetails $\& \mathrm{id}=$ 129173 on 2018-06-19

Reuscher M.G., Fiege D. 2016. Ampharetidae (Annelida: Polychaeta) from cold seeps off Pakistan and hydrothermal vents off Taiwan, with the description of three new species // Zootaxa. Vol.4139. No.2. P.197-208. https://doi.org/10.11646/zootaxa.4139.2.4

Responsible editor T.A. Britaev 